\title{
A Study Of Gender Differences With Respect To Internet Socialization Of Adolescents
}

Matthew E. Swinarski, Penn State Erie, USA Diane H. Parente, Penn State Erie, USA Kathleen Noce, Penn State Erie, USA

\begin{abstract}
This study investigates the differences between adolescent males and females in the perceived amount of knowledge regarding internet usage provided by various socialization agents (i.e. parents, school, media, and peers). Further, it examines whether there is a significant difference in the amount of knowledge regarding internet usage provided by various socialization agents within gender. The study takes a social learning perspective to examine the gender differences.
\end{abstract}

Keywords: technological socialization, social learning theory, socialization agents, gender differences

\section{INTRODUCTION}

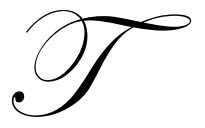

he Internet has permeated every part of our everyday lives - work, school, commerce, news, advice, communication, entertainment, and personal relationships (2005 Digital Future Report, 2005). This is specifically true for the $\mathrm{Y}$ generation which has grown up with the Internet and where acquiring the skills to effectively and efficiently use the Internet are believed to be critical to future academic and career success (Hargittai \& Shafer, 2006; H. Ono \& Zavodny, 2005). While recent findings have found evidence to suggest that the gender divide with respect to Internet access and usage is disappearing (Hargittai \& Shafer, 2006; Hiroshi Ono \& Zavodny, 2003; Wasserman \& Richmond-Abbott, 2005), other research warns that gender differences with respect to the Internet are still present, specifically in Internet-related activities, attitudes, and selfefficacy (Hargittai \& Shafer, 2006; Joiner, Brosnan, Duffield, Gavin, \& Maras, 2007; Morahan-Martin \& Schumacher, 2007). Morahan-Martine and Schumacher (2007) suggest that these gender differences still exist because "early socialization with computers and the Internet appears to favor boys" (p.2237). Almost a decade before, based on a review of 82 studies of gender differences with respect to computers, Whitley (1997) also suggested that socialization processes of boys and girls are the likely cause of gender differences with respect to technology.

Therefore, taking a social learning perspective, this research examines if there are differences in the way boys and girls are socialized to the Internet. Specifically, this study will investigate if 1) there is a significant difference between adolescent males and females in the perceived amount of knowledge regarding internet usage provided by various socialization agents (i.e. parents, school, media, and peers) and 2) within gender, there is a significant difference in the amount of knowledge regarding internet usage provided by various socialization agents.

The remainder of the paper is organized as follows: literature review of socialization in general, followed by the influence of various socializations agents, procedures and methodology, analysis and results, discussion and conclusions, and limitations and future research. 


\section{LITERATURE REVIEW}

\section{Socialization}

Socialization has been defined as " the process by which we learn the ways of a given society or social group so that we can function within it" (Elkin \& Handel, 1989, p. 2). The concept of socialization has roots in social learning theory, where the individual being socialized is portrayed as passively learning from direct interaction with other individuals (McLeod \& O'Keefe, 1972). The purveyors of social knowledge are referred to as socialization agents. Socialization agents may be any person, institution, or organization directly involved with the individual. However, over the past 30 years the main agents for socialization have been clearly delineated as parents, media, peers and educational institutions (Churchill \& Moschis, 1979; Moschis \& Churchill, 1978; Moschis, Moore, \& Smith, 1983; Olshavsky \& Granbois, 1979).

While the process of socialization happens throughout one's entire life (Rosenberg \& Turner, 1990, p. 159), most socialization research has focused on the pre-adult stages. In addition to life stage, socialization has been also studied in a variety of arenas. These include but are not limited to social class socialization (Petersen, Lee, \& Ellis, 1982) and cultural socialization (see for example Clugston, Howell, \& Dorfman, 2000; Ellis, Lee, \& Petersen, 1978). Of particular interest has been the study of gender socialization (see for example Dedovic, Wadiwalla, Engert, \& Pruessner, 2009; Dill \& Thill, 2007; Ventoura, Neokosmidi, Theofilou, \& Ioannidis, 2007). Socialization studies have been conducted in the context of leisure activities (Arnon, Shamai, \& Ilatov, 2008), children's health (Tinsley, 1992), product and service consumption (see for example Bao, Fern, \& Sheng, 2007; Lueg \& Finney, 2007) and consumer credit (see for example Lea, Webley, \& Walker, 1995; Palmer, Pinto, \& Parente, 2001; Pinto, Parente, \& Mansfield, 2005). This research extends the current socialization literature by examining gender difference in the socialization of pre-adults to the Internet.

\section{Influence Of Socialization Agents}

\section{Role of Parents}

The majority of research on socialization has identified primary agents, specifically parents, as the most influential (Bao, et al., 2007; Lueg \& Finney, 2007; Moschis \& Churchill, 1978; Moschis, et al., 1983; Pinto, et al., 2005). Although the popular press depicts today's parents as less technology savvy compared to their children, parents may still play a significant role in socializing their children to the Internet. In a study of male and female high school students, Shashaani (1994) found that parents' encouragement influenced both boys and girls attitudes toward computers; however, the study also revealed that females attitudes towards information technology were significantly lower if they perceived their parent thought computers were more appropriate for males. In a study of 202 college students, Shashaani (1997) also found that a pro-male bias by parents with respect to computers reduces their daughters' interest in computers. Through in-depth interviews, Kekelis, et al. (2005) observed that adolescent girls perceived that their parents provided them with less computer-related support. Shashaani (1997) speculated that bias at home with respect to computer usage may also cross over to Internet usage. Thus, the influence of parents with respect to socializing pre-adults to the Internet will be higher in males than in females.

\section{Role Of Schools}

Studies have shown that interest in computer-related studies, especially in female students, is highly influenced by the type of encouragement they receive in school (Beyer, 2008; Beyer \& Haller, 2006; Zarrett, Malanchuk, Davis-Kean, \& Eccles, 2006). Cole, et al. (1994) and Huber and Schofield (1998) found that teachers are more encouraging of males with respect to computer technology than females. Further, Culley (1988) observed that middle-school teachers assessed female computing competency lower than their male counterparts even when female students performed the same quality and quantity of work as the male students. Thus, the influence of schools with respect to socializing pre-adults to the Internet will be higher in males than in females. 
Role Of Media

Various media sources (including magazines, books and television) are also seen as playing a role in how males and females are socialized to the Internet. Early research by Ware and Stuck (1985) investigating the gender stereotyping with respect to computers and software in magazines found that females were not only underrepresented but also portrayed less favorably. Women were often depicted as being less experienced and more passive users of technology. Extending the research to include computer and software related advertisements on the Internet, television and movies, Knupfer (1998) found similar gender stereotyping. Although more recent research (Johnson, Rowan, \& Lynch, 2006) has noted a decline in the negative representation of women with respect to technology in the media, their research did find evidence that male computer stereotyping still exists. Thus, the influence of the media with respect to socializing pre-adults to the Internet will be higher in males than in females.

\section{Role Of Peers}

Peers tend to have greater social influence during the later stages of childhood and adolescent development. A study by Ching, Kafait \& Marshall (2002), investigating the computer task preference of male and female students, revealed male students to be more individualistic when doing computer related tasks while female students prefer to work collaboratively. Using an experimental design involving pairs of task performers and task observers, Corston and Colman (1996) found that females, unlike males, performed much better on computer tasks in the presence of female observers than alone or with a male observer. Thus, the influence of peers with respect to socializing pre-adults to the Internet will be higher in females than in males.

\section{Role Of Personal Experience}

The traditional socialization agents (parents, school, media, and peers) have been studied extensively. While traditional agents are important in this study, there is a need to extend the agents to include personal experiences as an influencing factor (see for example Arnon, et al., 2008; Leaper \& Brown, 2008). The concept of active learning or learning by doing has become common in both formal and informal educational settings (Gujarathi \& McQuade, 2002; Heriot, Cook, Jones, \& Simpson, 2008; Krell, 2007). Personal experiences can be considered learning by doing.

Since males are socialized more to technology in schools and at home, we postulate that males would be more confident in taking advantage of personal experience, particularly the trial-and-error aspect, and obtain a greater amount of information from personal experience than females.

\section{PROCEDURES}

\section{Method}

Surveys were administered by the researchers to a convenience sample of high school students attending a summer program $(n=154)$. The students were selected from a northeastern state with the criteria of both high interest and ability across the entire state. Human subjects' institutional research board approval was obtained including parental consent as appropriate.

There were 154 surveys distributed with 143 valid responses. Of these, $80 \%$ of the students were Caucasian with the remainder of various other ethnicities. The sample was $62.2 \%$ male and an age range of 15 to 18 , although over $90 \%$ of the total sample was either 16 or 17 years old.

\section{Constructs}

Socialization agents are the sources of information about the specific area of group membership and have been used in many prior studies. The conventional agents as defined in prior literature (see for example Arnon, et al., 2008; Moschis \& Churchill, 1978) are parents, peers, school, and media. However, given the Internet's influence on modern society, Roedder-John's (1999) suggestion that the Internet should be considered another socialization 
agent leads us to consider personal experience on the Internet as an additional agent. Thus, respondents were asked in this study to assess the amount of information regarding the Internet provided from each of the four traditional agents as well as personal experience.

\section{ANALYSIS AND RESULTS}

The first research question was "Is there a significant difference between males and females in the perceived amount of information provided by various socialization agents?" An independent sample t-test by gender was performed to answer this question.

The results shown in Table 1 illustrate a significant difference between males and females in the perceived information provided by each of the socialization agents. Males receive significantly more information than females from school and media socialization agents, while females receive significantly more information than males from peers, personal experience, and parents.

Table 1: Gender Differences in Information Provided by Socialization Agents

\begin{tabular}{|l|c|c|c|c|}
\hline \multicolumn{1}{|c|}{ Agents } & Females & Males & t-value & p-value \\
\hline Parents & 3.91 & 3.17 & 2.14 & .034 \\
\hline School & 4.63 & 5.44 & -2.49 & .014 \\
\hline Media & 4.43 & 5.09 & -2.01 & .047 \\
\hline Peers & 5.02 & 4.04 & 3.08 & .003 \\
\hline Personal Experience & 5.43 & 3.64 & 5.45 & .000 \\
\hline
\end{tabular}

Based on the propositions stated above, females perceive that they obtain significantly more information than males from parents. Thus, our proposition is not supported.

Males perceive that they receive significantly more information than females from school and also from media. This is consistent with our propositions.

Females perceive that they receive significantly more information from peers than males. This is also consistent with our prior proposition.

Finally, females perceive that they receive significantly more information than males from personal experience. This is not consistent with our prior proposition.

The second research question is "Is there a significant difference by gender between the agents in the amount of information provided?" A paired sample t-test was conducted to identify the between-agent differences. The test was performed on the useable sample (total 143) of 54 females and repeated for the sample of 89 males. The results are shown in Table 2 and Table 3 respectively.

Table 2: Paired Sample t-Tests of Socialization Agents for Females

\begin{tabular}{|l|c|c|c|c|c|c|}
\hline \multicolumn{1}{|c|}{ Source } & Mean & SD & $\begin{array}{c}\text { Personal } \\
\text { Experience }\end{array}$ & Peers & School & Media \\
\hline & $\mathbf{N}=\mathbf{5 4}$ & & \multicolumn{4}{|c|}{ t-value (sig.) } \\
\hline Personal Experience (on the internet) & 5.43 & 1.74 & & & & \\
\hline Peers & 5.02 & 1.78 & 1.33 & & & \\
\hline School (teachers or courses) & 4.63 & 1.88 & $2.36 *$ & 1.23 & & \\
\hline Media (TV, radio, books, print materials) & 4.43 & 1.99 & $2.87 * *$ & 1.93 & .74 & \\
\hline Parents & 3.91 & 1.95 & $4.63 * * *$ & $2.97 * *$ & $2.02 *$ & 1.41 \\
\hline$* * * \mathrm{p}<.001$ & $* * \mathrm{p}<.01$ & $* \mathrm{p}<.05$ & & & & \\
\hline
\end{tabular}


As shown in Table 2, for females, Personal Experience provides significantly more information than School $(\mathrm{t}=-2.36 ; \mathrm{p}<.05)$, more information than Media $(\mathrm{t}=2.87 ; \mathrm{p}<.01)$, and more information than Parents $(\mathrm{t}=4.63$; $\mathrm{p}<.001)$. Peers $(\mathrm{t}=2.97 ; \mathrm{p}<.01)$ and School $(\mathrm{t}=2.02 ; \mathrm{p}<.05)$ provide significantly more information than Parents.

In the case of males as shown in Table 3, School provides significantly more information than Peers $(\mathrm{t}=4.99 ; \mathrm{p}<.001)$, Personal Experience $(\mathrm{t}=5.43 ; \mathrm{p}<.001)$, or Parents $(\mathrm{t}=7.26 ; \mathrm{p}<.001)$. Media sources also provide more information than Peers $(\mathrm{t}=4.49 ; \mathrm{p}<.001)$, Personal Experience $(\mathrm{t}=4.20 ; \mathrm{p}<.001)$, or Parents $(\mathrm{t}=6.33 ; \mathrm{p}<.001)$. Peers provide significantly more information than Parents $(t=3.10 ; \mathrm{p}<.05)$.

Table 3: Paired Sample t-Tests of Socialization Agents for Males

\begin{tabular}{|l|c|c|c|c|c|c|}
\hline \multicolumn{1}{|c|}{ Source } & Mean & SD & School & Media & Peers & $\begin{array}{c}\text { Personal } \\
\text { Experience }\end{array}$ \\
\hline & $\mathbf{N}=\mathbf{8 9}$ & & \multicolumn{3}{|c|}{ t-value (sig.) } & \\
\hline $\begin{array}{l}\text { School (teachers or } \\
\text { courses) }\end{array}$ & 5.44 & 1.88 & & & & \\
\hline $\begin{array}{l}\text { Media (TV, radio, books, } \\
\text { print materials) }\end{array}$ & 5.09 & 1.88 & 1.55 & & & \\
\hline Peers & 4.04 & 1.87 & $4.99^{* * * *}$ & $4.49^{* * * *}$ & & \\
\hline $\begin{array}{l}\text { Personal Experience (on } \\
\text { the internet) }\end{array}$ & 3.64 & 2.13 & $5.43^{* * * *}$ & $4.20^{* * *}$ & 1.47 & \\
\hline Parents & 3.17 & 2.04 & $7.26^{* * *}$ & $6.33^{* * * *}$ & $3.08^{* * *}$ & 1.57 \\
\hline$* * * \mathrm{p}<.001$ & $* * \mathrm{p}<.01$ & $* \mathrm{p}<.05$ & & & & \\
\hline
\end{tabular}

In the next section, we will discuss the results and draw some conclusions.

\section{DISCUSSION AND CONCLUSIONS}

Past research has speculated that the potential differences in the way boys and girls are socialized to technology may influence the way males and females use technology in later years and perhaps eventual career choices. Our research does suggest that boys and girls are socialized to the Internet differently. The hypotheses demonstrated differences in the proposed direction with the exception of parents' and personal experience influence. Results show that females, more so than males, identified larger amounts of information coming from more personal sources, such as peers and parents, while males identified larger amounts of information coming from external sources, such as school and media. This is reasonable given that females prefer a more collaborative environment.

What was surprising is that the females, when compared to males, believed that they received the larger amount of information from their personal experience with the internet. This is surprising since past research has stated that males tend to be more playful, explorative, and individualistic. However, additional analysis reveals that knowledge from peers and the internet were highly correlated with one another (no other pair of sources were significantly correlated with each); therefore, females may perceive the internet as being a more personal and cooperative environment than individualistic and competitive. Given the perceived lack of information from traditional school settings for females, it may also be that females have taken it upon themselves to develop their own skills. Girls may feel more comfortable exploring these arenas on their own instead of in a public or less private setting.

Though parents often are the most influential socialization agent in other areas, with respect to learning about the Internet, parents play the least significant role for both males and females. Even with increasing access to computers in the home, parents provide significantly less information than any other source. This may be due to a generational or age gap. Our sample was 16-17 year olds with most parents likely to be in their 40's. These parents were not raised with computers and are not as likely to exude proficiency. This generation of adolescents is the first to grow up with computers and the internet. Unlike their parents, they have been exposed to computers and the Internet at a very early age. However, it is becoming increasingly more common for young children to see parents at home with a computer and for children to receive a computer (with learning programs) at a young age. Thus, children should be more likely to learn about technology, computers, and the internet from their parents in the 
future. Therefore, we speculate that the parents' influence will increase over time.

The outcome of this study is that there is a clear delineation in the sources or agents by which students become acclimated to technology. Further, this difference is significant by gender. It is important for our society, in general, to recognize these differences and properly address them so females and males have both equal exposure and opportunity. We also need to work toward removing the stigma that females still face with science, math, and technology. Reducing this stigma may go a long way toward equalizing the gender gap in the socialization of technology.

\section{LIMITATIONS AND FUTURE RESEARCH}

There are several limitations in this study. We only looked at socialization agents and gender. We should look at internet usage in more specific terms, including what students are doing with the computer. Are there correlations between what they are doing and who socialized them? Do their prior dispositions - for example, primary areas of interest - change the perceived agents? Does the role of parents change as parents become more computer savvy? Finally, since we investigated high school students, is there a difference between age groups? Do college students follow the same patterns regarding the importance of socialization agents? Perhaps we should repeat this study over time and with different life stages.

\section{AUTHOR INFORMATION}

Matthew Swinarski, Ph.D. is Assistant Professor of MIS in the Black School of Business at Penn State Erie, The Behrend College. He received his Ph.D. from the University at Buffalo. His active research areas are IS sourcing and IS education. His papers have been published in Communications of the ACM, Decision Support Systems, Communications of the AIS and Advances in Management Information Systems, and he has presented his research at numerous conferences including ICIS, AMCIS, HICSS, and DSI. He was also Issue Managing Editor for the Journal of Information Technology Theory and Application. His industry experience includes installation, configuration, and service contact management of enterprise applications.

Diane H. Parente, Ph.D. is Professor of Management in the Black School of Business at Penn State Erie, The Behrend College. She received her PhD from the University at Buffalo. She has extensive industry experience logistics, operations, management information systems, and strategic business unit management. Her research interests revolve around the cross-functional aspects of business. She has published in numerous journals including Information Resources Management Journal, Interfaces, IJOPM, and the Communications of the ACM. She also has authored a book on Best Practices in Online Procurement Auctions. Dr. Parente is a member of the Academy of Management, DSI, and POMS.

Kathleen Noce, D.Ed. is Lecturer in MIS in the Black School of Business at Penn State Erie, The Behrend College. She received her D.Ed. from Indiana University of Pennsylvania. Her research interests include Internet issues related to marketing, social concerns and e-commerce, information systems and technological leadership. Her work has appeared in the Journal of Behavioral Studies in Business. She has also presented her research at numerous conferences including DSI, MWDSI, and the Academy of Management. Dr. Noce has previous industry experience in systems analysis and design in the financial sector and information technology management.

\section{REFERENCES}

1. 2005 Digital Future Report (2005). Los Angeles: USC Annenberg School.

2. Arnon, S., Shamai, S., \& Ilatov, Z. (2008). Socialization agents and activities of young adolescents. Adolescence, 43(170), 373-397.

3. Bao, Y., Fern, E. F., \& Sheng, S. (2007). Parental style and adolescent influence in family consumption decisions: An integrative approach. Journal of Business Research, 60(7), 672-680.

4. Beyer, S. (2008). Gender Differences and Intra-Gender Differences amongst Management Information Systems Students Journal of Information Systems Education, 19(3), 301-310. 
5. Beyer, S., \& Haller, S. (2006). Gender differences and intra-gender differences in Computer Science students: Are female CS majors more similar to male CS majors or female non-majors? . Journal of Women and Minorities in Science and Engineering, 12(4), 337-365.

6. Ching, C. C., Kafai, Y. B., \& Marshall, S. K. (2002). I always get stuck with the books": Creating space for girls to access technology in a software design project.

7. In N. Yelland \& A. Rubin (Eds.), Ghosts in the Machine: Women's Voices in Research with Technology (pp. 167-189). New York: Peter Lang Publishing, Inc.

8. Churchill, G. A., \& Moschis, G. P. (1979). Television and Interpersonal Influences on Adolescent Consumer Learning. Journal of Consumer Research, 6(1), 22-35.

9. Clugston, M., Howell, J. P., \& Dorfman, P. W. (2000). Does Cultural Socialization Predict Multiple Bases and Foci of Commitment? Journal of Management, 26(1), 5-30.

10. Cole, A., Conlon, T., Jackson, S., \& Welch, D. (1994). Information technology and gender: Problems and proposals Gender and Education, 6(1), 77-85.

11. Corston, R., \& Colman, A. M. (1996). Gender and social facilitation effects on computer competence and attitudes toward computers. Journal of Educational Computing Research, 14(2), 171-183.

12. Culley, L. (1988). Girls, boys and computers Educational Studies, 14(1), 3-8.

13. Dedovic, K., Wadiwalla, M., Engert, V., \& Pruessner, J. C. (2009). The Role of Sex and Gender Socialization in Stress Reactivity. Developmental Psychology, 45(1), 45-55.

14. Dill, K. E., \& Thill, K. P. (2007). Video Game Characters and the Socialization of Gender Roles: Young People's Perceptions Mirror Sexist Media

15. Depictions. Sex Roles, 57, 851-864.

16. Elkin, F., \& Handel, G. (1989). The child and society: The process of socialization (5th ed.). New York: McGraw Hill.

17. Ellis, G. J., Lee, G. R., \& Petersen, L. R. (1978). Supervision and Conformity: A Cross-Cultural Analysis of Parental Socialization Values. The American Journal of Sociology, 84(2), 386-403.

18. Gujarathi, M. R., \& McQuade, R. J. (2002). Service-learning in business schools: A case study in an intermediate accounting course. Journal of Education for Business, 77(3), 144-150.

19. Hargittai, E., \& Shafer, S. (2006). Difference in actual and perceived online skills: The role of gender. Social Science Quarterly, 87(2), 432-448.

20. Heriot, K. C., Cook, R., Jones, R. C., \& Simpson, L. (2008). The Use of Student Consulting Projects as an Active Learning Pedagogy: A Case Study in a Production/Operations Management Course. Decision Sciences Journal of Innovative Education, 6(2), 463-481.

21. Huber, B. R., \& Schofield, J. W. (1998). I like computers, but many girls don't": Gender and the sociocultural context of computing In H. Bromley \& M. W. Apple (Eds.), Education/Technology/Power: Educational Computing as a Social Practice (pp. 103-131). Albany: State University of New York Press.

22. Johnson, N. F., Rowan, L., \& Lynch, J. (2006). Constructions of Gender in Computer Magazine Advertisements: Confronting the Literature. Studies in Media \& Information Literacy Education, 6(1), 1-9.

23. Joiner, R., Brosnan, M., Duffield, J., Gavin, J., \& Maras, P. (2007). The relationship between Internet identification, Internet anxiety and Internet use. Computers in Human Behavior 23(3), 1408-1420.

24. Kekelis, L. S., Ancheta, R. W., \& Heber, E. (2005). Hurdles in the pipeline: Girls and technology careers. Frontiers: A Journal of Women Studies, 26(1), 99-109.

25. Knupfer, N. N. (1998). Gender divisions across technology advertisements and the WWW: Implications for educational equity. Theory into Practice, 37(1), 54-63.

26. Krell, E. (2007). The business of business schools is changing. Baylor Business Review, 25(2), 4-11.

27. Lea, S. E. G., Webley, P., \& Walker, C. M. (1995). Psychological factors in consumer debt: Money management, economic socialization, and credit use. Journal of Economic Psychology, 16(4), 681-701.

28. Leaper, C., \& Brown, C. S. (2008). Perceived experiences with sexism among adolescent girls. Child Development, 79(3), 685-704.

29. Lueg, J. E., \& Finney, R. Z. (2007). Interpersonal communication in the consumer socialization process: Scale development and validation. Journal of Marketing Theory and Practice, 15(1), 25-39.

30. McLeod, J. M., \& O'Keefe, G. J. J. (1972). The socialization prospective and communication behavior. In G. Kline \& P. Tichenor (Eds.), Current Perspectives in Mass Communication Research. Beverly Hills, CA: Sage. 
31. Morahan-Martin, J., \& Schumacher, P. (2007, August). How gender influences uses of health information from the Internet. Paper presented at the Convention of the American Psychological Association, San Francisco, CA.

32. Moschis, G. P., \& Churchill, G. A. (1978). Consumer Socialization: A Theoretical and Empirical Analysis. Journal of Marketing, 15, 599-609.

33. Moschis, G. P., Moore, R. L., \& Smith, R. B. (1983). The Impact of Family Communications on Adolescent Consumer Socialization. Paper presented at the Association for Consumer Research, Provo, UT.

34. Olshavsky, R. W., \& Granbois, D. H. (1979). Consumer Decision Making-Fact or Fiction? The Journal of Consumer Research, 6(2), 93-100.

35. Ono, H., \& Zavodny, M. (2003). Gender and the Internet. Social Science Quarterly, 84, 111-121.

36. Ono, H., \& Zavodny, M. (2005). Gender differences in information technology usage: A US-Japan comparison. Sociological Perspectives 48(1), 105-113.

37. Palmer, T. S., Pinto, M. B., \& Parente, D. H. (2001). College Students' Credit Card Debt and the Role of Parental Involvement: Implications for Public Policy. Journal of Public Policy \& Marketing, 20(1), 105113.

38. Petersen, L. R., Lee, G. R., \& Ellis, G. J. (1982). Social Structure, Socialization Values, and Disciplinary Techniques: A Cross-Cultural Analysis. Journal of Marriage and the Family, 44(1), 131-142.

39. Pinto, M. B., Parente, D. H., \& Mansfield, P. (2005). Information Learned from Socialization Agents: Its Relationship to Credit Card Usage. Family and Consumer Science Research Journal, 33(4), 357-367.

40. Roedder-John, D. (1999). Consumer Socialization of Children: A Retrospective Look at Twenty-Five Years of Research. Journal of Consumer Research, 26, 183-213.

41. Rosenberg, M., \& Turner, R. H. (1990). Social psychology: VNU Business Media, Inc.

42. Shashaani, L. (1994). Socioeconomic status, parents' sex-role stereotypes, and the gender gap in computing Journal of Research on Computing in Education, 26(4), 433-451.

43. Shashaani, L. (1997). Gender differences in computer attitudes and use among college students. Journal of Educational Computing Research, 16(1), 37-51.

44. Tinsley, B. J. (1992). Multiple Influences on the Acquisition and Socialization of Children's Health Attitudes and Behavior: An Integrative Review. Child Development, 63(5), 1043-1069.

45. Ventoura, Z., Neokosmidi, A., Theofilou, A., \& Ioannidis, P. (2007). Women Equality In Labour Market: A Myth Or A Reality? The Case Of Women PR Managers. Journal of Diversity Management, 2(4), 61-68.

46. Ware, M. C., \& Stuck, M. F. (1985). Sex-role messages vis-à-vis microcomputer use: A look at the pictures. Sex Roles: A Journal of Research, 13(3/4), 205-214.

47. Wasserman, I. M., \& Richmond-Abbott, M. (2005). Gender and the Internet: Causes of variation in access, level, and scope of use. Social Science Quarterly, 86(1), 252-270.

48. Whitley, B. E., Jr. (1997). Gender differences in computer-related attitudes and behavior: A meta-analysis Computers in Human Behavior, 13(1), 1-22.

49. Zarrett, N. R., Malanchuk, O., Davis-Kean, P. E., \& Eccles, J. (2006). Examining the gender gap in IT by race: Young adults' decisions to pursue an IT career. In J. M. Cohoon \& W. Aspray (Eds.), Women and Information Technology: Research on underrepresentation (pp. 5588). Cambridge, MA: MIT Press. 